\title{
Does informal risk capital relax the financial constraints of high-tech entrepreneurial ventures?
}

\author{
Massimo G. Colombo ${ }^{\mathrm{a}}$, Annalisa Croce ${ }^{\mathrm{a}, *}$ and Massimiliano Guerini ${ }^{\mathrm{b}}$ \\ ${ }^{\mathrm{a}}$ DIG, Politecnico di Milano, Via Lambruschini 4b, 20156 Milan, Italy \\ ${ }^{\mathrm{b}}$ DESTEC, University of Pisa, Largo Lazzarino, 56122 Pisa, Italy
}

This work analyses the effect of informal risk capital financing on a firm's investment/cash flow sensitivity (ICFS) in a sample of 498 Italian privately held high-tech entrepreneurial ventures (HTEVs) observed from 1996 to 2008. To detect financial constraints, we resort to an error correction model (ECM). We find that the receipt of informal risk capital in the seed stage results in reduced ICFS, indicating a persistent relaxation of financial constraints.

Keywords: informal risk capital; financial constraints; error correction model; high-tech entrepreneurial ventures

JEL classifications: G31; G24; D92

\section{Introduction}

High-tech entrepreneurial ventures (HTEVs) play a cru-cial role in modern economies (Audretsch, 1995). However, hidden information and hidden action problems make it difficult for these firms to obtain external finan-cing (Hall, 2002). Recent literature suggests that venture capital (Bertoni et al., 2010) and public subsidies (Czarnitzki, 2006; Colombo et al., 2012a) help to relax the financial constraints of HTEVs. However, institutional venture capital and public subsidies are not the only source of financing for HTEVs and neither are they the most popular. The provision of informal risk capital, i.e., capital provided by family, friends and business angels (Shane, 2012) plays indeed a major role in the financing of HTEVs. Using a sample of US small firms in 1993, Berger and Udell (1998) document that informal risk capital accounted for an estimated $16.45 \%$ of the total funding (i.e., equity and debt) provided to small firms, while institutional venture capital only accounted for $1.85 \%$. Using data from the Global Enterprise Monitor, Mason (2007) reports that informal risk capital accounted for between $60 \%$ and $90 \%$ of total early stage capital provided by informal and institutional investors. ${ }^{1}$

Despite the size of the informal risk capital market, there is little evidence of its efficacy in removing the financial constraints of HTEVs. A few studies in the US (Kerr et al., 2013, forthcoming) and Belgium (Collewaert et al., 2010) suggest that receipt of risk capital from business angel networks (BANs) has a positive impact on the firm's subsequent fund-raising. However, these studies focus on one particular category of informal risk capital investors, i.e., business angels affiliated with established BANs. Therefore, the magnitude of the estimated impact is likely to be located at the upper end of the population of informal risk capital investors. The current study aims to fill this gap by estimating whether receipt of informal risk capital in the seed stage relaxes the financial

*Corresponding author. E-mail: annalisa.croce@polimi.it

${ }^{1}$ For Italy, the country covered in this study, the Italian Business Angel Network (IBAN) states that business angel deals as in 2011 accounted for greater than $70 \%$ of the total number of early stage deals (http://www.iban.it/wp-content/uploads/2012/11/ComunicatoStampa-IBAN+VeM_latest.pdf). Because business angels affiliated to IBAN represent only a portion of informal risk capital investors, the total size of the Italian informal risk capital market is likely to be quite large. 
constraints of HTEVs. We resort to investment/cash flow sensitivity (ICFS) as an indicator of the presence of financial constraints (Fazzari et al., 1988). Although the question has arisen of whether ICFS reflects the presence of financial constraints, in this study, we focus attention on privately held owner-managed HTEVs. For these firms, the arguments that question the link between ICFS and the presence of financial constraints are quite implausible (Colombo et al., 2013). We argue that if receipt of informal risk capital in the seed stage allows recipient firms to remove their financial constraints, this results in a persistent (i.e., long run) increase of the firm's investment rate and a reduction of the ICFS.

\section{Econometric Specification}

Recent works propose the use of an error correction model (ECM) to estimate investment dynamics (e.g., Guariglia, 2008). Accordingly, we use an augmented version of the standard ECM (Bond et al., 2003) by including the variable $I R C_{i}$, which equals 1 if the focal firm received informal risk capital (defined as equity capital provided by individual investors with no operating role in the firm's management) in the seed stage (i.e., at firm foundation). Specifically:

$$
\begin{aligned}
\frac{I_{i, t}}{K_{i, t-1}}= & \alpha_{0}+\beta_{1} \frac{I_{i, t-1}}{K_{i, t-2}}+\beta_{2} \Delta y_{i, t}+\beta_{3} \Delta y_{i, t-1} \\
& +\beta_{4}\left(k_{i, t-2}-y_{i, t-2}\right)+\beta_{5} \frac{C F_{i, t}}{K_{i, t-1}} \\
& +\beta_{6} I R C_{i}+\beta_{7} I R C_{i} \times \frac{C F_{i, t}}{K_{i, t-1}}+\varepsilon_{i, t}
\end{aligned}
$$

$I_{i, t}$ is the level of the firm's $i$ investment in period $t$, as measured by the increase in the book value of fixed assets net of depreciation, $K_{i, t}$ is the end-of-period $t$ book value of the firm's $i$ assets and $k_{i, t}$ is its logarithm, $C F_{i, t}$ is the firm's $i$ cash flow in period $t$ after taxes but before dividends and $y_{i, t}$ is the logarithm of the firm's $i$ sales during period $t$. The coefficient $\beta_{5}$ measures the ICFS of firms that did not receive any informal risk capital in the seed stage. We expect $\beta_{5}>0$, indicating the presence of
Table 1. Summary statistics on regression variables

\begin{tabular}{llrllr}
\hline Variable & $\mathrm{N}$ & Mean & SD & Min & Max \\
\hline$I_{i, t} / K_{i, t-1}$ & 3068 & 0.80 & 1.53 & -0.27 & 9.93 \\
$\Delta y_{i, t}$ & 3068 & 0.12 & 0.44 & -1.06 & 2.50 \\
$\left(k_{i, t-2}-y_{i, t-2}\right)$ & 3068 & -1.94 & 1.32 & -4.50 & 2.00 \\
$C F_{i, t} / K_{i, t-1}$ & 3068 & 0.84 & 1.72 & -2.56 & 10.10 \\
$I R C_{i}$ & 3068 & 0.28 & 0.45 & 0.00 & 1.00 \\
\hline
\end{tabular}

financial constraints. The coefficients $\beta_{6}$ and $\beta_{7}$, respectively, capture the differences in the investment rate and in the ICFS between HTEVs that received informal risk capital and those that did not. ${ }^{2}$ To assess whether HTEVs that receive informal risk capital are financially constrained, we perform the following $t$-test under the null hypothesis that a change in cash flow does not affect the investment rate: $\beta_{5}+\beta_{7}=0$. Table 1 reports the summary statistics of regression variables. ${ }^{3}$

To account for the endogeneity of covariates, we resort to the two-step system generalized method of moments estimation (Blundell and Bond, 1998) with finite-sample correction (Windmeijer, 2005). ${ }^{4}$ We consider $I_{i, t} / K_{i, t-1}$, $\Delta y_{i, t},\left(k_{i, t}-y_{i, t}\right)$ and $C F_{i, t} / K_{i, t-1}$ to be endogenous. ${ }^{5}$ To evaluate the relevance of our econometric model, we implement the Arellano and Bond test for the first- and second-order serial autocorrelation of the residuals [AR (1), AR(2)]. Moreover, the Hansen-J test is also implemented to verify the validity of the specified orthogonality conditions.

\section{Data}

We use a sample of 498 privately held Italian HTEVs operating in the manufacturing and services sectors. The sample firms were established in 1983 or later and are observed during the period 1996-2008. Of the 498 HTEVs in the sample, 157 received informal risk capital in the seed stage. The sample also includes 122 HTEVs that received venture capital or public subsidies during the observation period. ${ }^{6}$ Out of these firms, 46 received informal seed risk capital.

\footnotetext{
${ }^{2}$ We also include area dummies, time dummies and industry dummies interacted with time dummies.

${ }^{3}$ All continuous variables have been winsorized with a $2 \%$ cut-off for each tail.

${ }^{4}$ The use of a large number of instruments may result in significant finite-sample bias. To address this problem, we limit the instrument set with moment conditions in the interval between $t-2$ and $t-3$ (see Bond, 2002).

${ }^{5}$ As to the endogeneity of $I R C_{i}$, one may wonder whether external factors may affect both the availability of informal risk capital and the financial constraints of high-tech entrepreneurial ventures (HTEVs). Accordingly, we considered the average interest rate on bank loan in the NUTS3 region in which HTEVoperates in order to control for the affordability of bank financing that makes informal risk capital less attractive and reduces financial constraints. Following a similar reasoning, we also considered population wealth proxied by value added per inhabitant. However, we did not detect any significant difference between firms that receive informal risk capital and those that did not. Furthermore, a reverse causality problem may affect our results as more financially constrained firms are allegedly more inclined to look for informal risk capital. However, this would generate an upward bias in the estimates of the relationship between informal risk capital and investment/cash flow sensitivity (ICFS), thereby making our results even stronger.

${ }^{6}$ We also estimated Equation 1 by excluding HTEVs from the year of receipt of the first round of venture capital or the first public subsidy (see Section IV).
} 


\begin{tabular}{|c|c|c|c|c|c|c|}
\hline & \multicolumn{2}{|c|}{ RITA directory } & \multicolumn{2}{|c|}{ Total sample } & \multicolumn{2}{|c|}{$\begin{array}{l}\text { Informal risk capital } \\
\text { sample }\end{array}$} \\
\hline & $N$ & $\%$ & $N$ & $\%$ & $N$ & $\%$ \\
\hline \multicolumn{7}{|l|}{ Industry } \\
\hline Biotechnology and pharmaceutical & 123 & 7.5 & 34 & 6.8 & 14 & 8.9 \\
\hline Other high-tech manufacturing $^{\mathrm{a}}$ & 600 & 36.3 & 185 & 37.1 & 56 & 35.7 \\
\hline Telecommunication and internet services & 418 & 25.3 & 121 & 24.3 & 33 & 21.0 \\
\hline Software & 424 & 25.7 & 136 & 27.3 & 44 & 28.0 \\
\hline Other high-tech services ${ }^{\mathrm{b}}$ & 86 & 5.2 & 22 & 4.4 & 10 & 6.4 \\
\hline \multicolumn{7}{|l|}{ Geographic area } \\
\hline Northwest & 657 & 39.8 & 209 & 42.0 & 62 & 39.5 \\
\hline Northeast & 376 & 22.8 & 106 & 21.3 & 33 & 21.0 \\
\hline Centre & 307 & 18.6 & 97 & 19.5 & 32 & 20.4 \\
\hline South & 311 & 18.8 & 86 & 17.3 & 30 & 19.1 \\
\hline Total & 1651 & 100.0 & 498 & 100.0 & 157 & 100.0 \\
\hline
\end{tabular}

Notes: ' 'Other high-tech manufacturing' includes the following industries: advanced materials, automation equipment and robotics, computers, electronic components, telecommunications equipment, and electronic, optical and medical instruments.

b'Other high-tech services' includes the following industries: environmental services and R\&D engineering.

The sample was extracted from the RITA (Research on Entrepreneurship in Advanced Technologies) directory. As of 1 January 2009, the RITA directory stored information on 1651 HTEVs that were representative of the Italian population of HTEVs by industry and geographic area (Colombo et al., 2012b). The sample includes all HTEVs for which we were able to build a complete data set relative to the variables of interest.

Table 2 reports the distribution across industries and geographic areas of the firms in the RITA directory (columns I and II), the sample firms (columns III and IV) and the sample firms that received informal risk capital (columns V and VI). Two $\chi^{2}$ tests show that there no statistically significant differences exist between the distributions of the 498 sample firms across industries and geographic areas and the corresponding distributions of the 1651 RITA firms $\left(\chi^{2}(4)=1.67\right.$ and $\chi^{2}(3)=1.93$, respectively). This observation also holds true when comparing the distributions of RITA firms and firms that received informal risk capital $\left(\chi^{2}(4)=2.36\right.$ and $\chi^{2}$ (3) $=0.49$, respectively)

\section{Results and Discussion}

Table 3 reports the estimates of Equation 1 for the total sample (Model I) and for a reduced sample obtained by excluding HTEVs after receipt of venture capital or public subsidies (Model II).

All models are correctly specified. The AR(1) and $\mathrm{AR}(2)$ tests confirm the presence of a negative first-order serial correlation and the null hypothesis of the absence of a second-order serial correlation is not rejected.
Table 3. Estimation results

\begin{tabular}{lcc}
\hline & Model I & Model II \\
\hline$I_{i, t-1} / K_{i, t-2}$ & $-0.050^{*}$ & $-0.059^{*}$ \\
$\Delta y_{i, t}$ & $(0.028)$ & $(0.033)$ \\
$\Delta y_{i, t-1}$ & $0.489^{*}$ & 0.420 \\
& $(0.261)$ & $(0.279)$ \\
$\left(k_{i, t}-y_{i, t}\right)$ & $0.348^{* * *}$ & $0.392^{* * *}$ \\
& $(0.119)$ & $(0.132)$ \\
$C F_{i, t} / K_{i, t-1}$ & $-0.168^{* *}$ & $-0.213^{* *}$ \\
$I R C_{i}$ & $(0.082)$ & $(0.098)$ \\
& $0.366^{* * *}$ & $0.295^{* * *}$ \\
$I R C_{i} \times C F_{i, t} / K_{i, t-1}$ & $(0.087)$ & $(0.088)$ \\
& $0.992^{* *}$ & 0.384 \\
Constant & $(0.465)$ & $(0.407)$ \\
& $-0.434^{* * *}$ & -0.259 \\
No. of observations & $(0.142)$ & $(0.214)$ \\
No. of firms & 0.285 & 0.443 \\
Hansen-J $(p$-value) & $(0.357)$ & $(0.389)$ \\
AR( 1$)$ & 3068 & 2690 \\
AR(2) & 498 & 448 \\
$\beta_{5}+\beta_{7}$ & 0.861 & 0.370 \\
& $-6.596^{* * *}$ & $-5.776^{* * *}$ \\
& 0.624 & 0.771 \\
& -0.068 & 0.037 \\
& $(0.106)$ & $(0.199)$ \\
\hline
\end{tabular}

Notes: Two-step system generalized method of moments estimates (Blundell and Bond, 1998) with finite-sample correction (Windmeijer, 2005). Area dummies, year dummies and year dummies interacted with industry dummies are omitted from the table. SE in parentheses. AR(1) and AR (2) are tests of the null hypothesis of, respectively, no first-and secondorder serial correlation. The Hansen-J is a test of the validity of the over-identifying restrictions. All con-tinuous variables are winsorized with a $2 \%$ cut-off for each tail. $* * *, * *$ and $*$ indicate significance levels of $1 \%, 5 \%$ and $10 \%$. 
Furthermore, the instruments are valid as suggested by the Hansen-J tests.

In all models $\beta_{1}, \beta_{2}, \beta_{3}$ and $\beta_{4}$ have the expected signs (Bond et al., 2003). Model I suggests that HTEVs that did not receive informal risk capital in the seed stage are financially constrained. The coefficient $\beta_{5}$ is positive and significant at $1 \%$ and is of large economic magni-tude: a $1 €$ increase in cash flow leads to a $0.37 €$ increase in the investment rate. ${ }^{7}$ Conversely, the ICFS of HTEVs that received informal risk capital (i.e., $\beta_{5}+\beta_{7}$ ) is not significant. We interpret these results as an indication of the relaxation of financial constraints. Furthermore, the investment rate of these latter firms is higher: the coefficient $\beta_{6}$ is indeed positive and significant at 5\%. Lastly, the results from Model II are partially in line with those of Model I. Indeed, the ICFS of HTEVs that received informal risk capital is again not significant, but the investment rate of these firms is not higher than those of other HTEVs (the coefficient $\beta_{6}$ is indeed not significant).

The relaxation of financial constraints can be explained by different effects. First, HTEVs that are backed by informal investors may obtain capital for investments from these investors when it is required (direct effect). Second, the HTEVs may use these capital injections to purchase tangible assets that can subsequently be used as collateral (Berger and Udell, 1990) or may have recourse to the external collateral provided by the informal inves-tors. In turn, this favours the receipt of bank credit (col-lateral effect). Third, the presence of informal investors increases the network of contacts of the HTEVs with other potential external investors (networking effect). We are not able to disentangle these different effects. However, the estimates of Model II show that if we include HTEVs that received venture capital or public subsidies, the effect of informal risk capital is stronger, resulting in a higher investment rate. This latter result is consistent with the 'networking effect'.

The most important limitation of this work is that we do not have data on the amount of informal risk capital received by the sample firms at foundation or on their subsequent capital injections. The availability of these data would allow a more precise assessment of three abovementioned effects. Nevertheless, our findings are consistent with the view that informal risk capital is an important source of seed financing for HTEVs. From a policy perspective, these results argue in favour of public support to stimulate informal risk capital. The TEPA law (Law no. 2007-1223, Loi en faveur du travail, de l'emploi et $d u$ pouvoir d'achat) in France and the Enterprise Investment Scheme in the UK provide interesting examples. ${ }^{9}$ In this area, policy measures that are aimed at favouring the development of business angel financing, e.g., though subsidies (Collewaert et al., 2010) or coinvestments schemes (e.g., the European Angels Fund promoted by the European Investment Fund), seem especially promising.

\section{References}

Audretsch, D. B. (1995) Innovation and Industry Evolution, MIT Press, Cambridge.

Berger, A. N. and Udell, G. F. (1990) Collateral, loan qual21-42. ity, and bank risk, Journal of Monetary Economics, 25,

Berger, A. N. and Udell, G. F. (1998) The economics of small business finance: the roles of private equity and debt markets in the financial growth cycle, Journal of Banking \& Finance, 22, 613-73.

Bertoni, F., Colombo, M. G. and Croce, A. (2010) The effect of venture capital financing on the sensitivity to cash flow of firm's investments, European Financial Management, 16, $528-51$.

Blundell, R. and Bond, S. R. (1998) Initial conditions and moment restrictions in dynamic panel data models, Journal of Econometrics, 87, 115-43.

Bond, S. R. (2002) Dynamic panel data models: a guide to micro data methods and practice, Portuguese Economic Journal, 1, 141-62.

Bond, S. R., Elston, J. A., Mairesse, J. et al. (2003) Financial factors and investment in Belgium, France, Germany, and the United Kingdom: a comparison using company panel data, Review of Economics and Statistics, 85, 153-65.

Collewaert, V., Manigart, S. and Aernoudt, R. (2010) Assessment of government funding of business angel networks in flanders, Regional Studies, 44, 119-30.

Colombo, M. G., Croce, A. and Guerini, M. (2012a) Is the Italian government effective in relaxing the financial constraints of high-tech firms? An analysis by firm's size, age and geographical area, Prometheus, 30, 73-96.

Colombo, M. G., Croce, A. and Guerini, M. (2013) The effect of public subsidies on firms' investment-cash flow sensitivity: transient or persistent?, Research Policy, 42, 1605-23.

Colombo, M. G., Piva, E., Quas, A. et al. (2012b) How are high tech entrepreneurial ventures coping with the global crisis? Product innovation and internationalization strategies, in Entrepreneurial Strategies and Policies for Economic Growth (Eds) M. Muffato and P. Giacon, Libreriauniversitaria.it, Padova, 373-91.

\footnotetext{
${ }^{7}$ We also estimate the error correction model (ECM) specification on a sample of HTEVs that did not receive informal risk capital. Results (not reported here) confirm that HTEVs are financially constrained.

${ }^{8}$ In line with this view, the estimates not reported in this work show that the likelihood of receiving venture capital is significantly higher for HTEVs that received informal risk capital at foundation.

${ }^{9}$ The TEPA law, introduced in 2007, allows French residents to deduct from the solidarity tax the wealth capital invested in small firms, up to $50000 €$. The Enterprise Investment Scheme provides an attractive tax relief to individual investors who provide funding to unlisted small firms. In Italy, public intervention in this area is limited to the introduction in 2008 of a tax relief scheme for business angel investments (European Commission, 2012).
} 
Czarnitzki, D. (2006) Research and development in small and medium-sized enterprises: the role of financial constraints and public funding, Scottish Journal of Political Economy, 53, 335-57.

European Commission (2012) Evaluation of EU member states' business angel markets and policies. Available at http://ec. europa.eu/enterprise/dg/files/ba-rep_en.pdf (accessed 10 July 2013).

Fazzari, S., Hubbard, R. G. and Petersen, B. (1988) Financing constraints and corporate investment, Brookings Papers on Economic Activity, 1988, 141-206.

Guariglia, A. (2008) Internal financial constraints, external financial constraints, and investment choice: evidence from a panel of UK firms, Journal of Banking \& Finance, 32, 1795-809.
Hall, B. H. (2002) The financing of research and development, Oxford Review of Economic Policy, 18, 35-51.

Kerr, W. R., Lerner, J. and Schoar, A. (2013, forthcoming) The consequences of entrepreneurial finance: evidence from angel financings, Review of Financial Studies. doi:10.1093/rfs/hhr098.

Mason, C. M. (2007) Informal sources of venture finance, in The Life Cycle of Entrepreneurial Ventures (Ed.) S. Parker, Springer, New York, pp. 259-99.

Shane, S. (2012) The importance of angel investing in financing the growth of entrepreneurial ventures, Quarterly Journal of Finance, 2, 1-42.

Windmeijer, F. (2005) A finite sample correction for the variance of linear efficient two-step GMM estimators, Journal of Econometrics, 126, 25-51. 